\title{
Enhancing Organizational Fit Factors to Achieve ERP Project Success
}

\author{
Shin-Yuan Hung \\ Department of Information Management, \\ National Chung Cheng University, \\ Chia-Yi, Taiwan, R.O.C. \\ syhung@mis.ccu.edu.tw \\ Wen-Ju Yu \\ Department of Information Management, \\ National Chung Cheng University, \\ Chia-Yi, Taiwan, R.O.C. \\ you168phd@gmail.com \\ Charlie C. Chen, \\ Department of Computer Information Systems, \\ Appalachian State University, North Carolina, USA. \\ chench@appstate.edu \\ Jung-Chang Hsu, \\ Department of Information Management, \\ National Chung Cheng University, \\ Chia-Yi, Taiwan, R.O.C. \\ jchsu666@yahoo.com.tw
}

\begin{abstract}
Organizational fit is an important project success factor; however, its importance and relationships with key project management (PM) factors in large-scale software projects have not been thoroughly investigated. The purpose of this paper is to investigate of the direct effect of organizational fit factor on ERP project success, and the moderating effect of organizational adaptation and PM factors on the relationship between organizational fit and ERP success. A total of 69 enterprisesin Taiwan were surveyed. The collected data were analyzed using the regression analysis. The data analysis results indicate that organizational fit has a direct and positive influence on ERP project success. Depends on project success measures (cost, time, performance, and benefit) to achieve, organization adaptation factors (i.e. system and business process adaptation) and key PM factors (i.e. teamwork, top management support, end-user training, and vendor's advising capability)play strong moderating roles in the relationship between organizational fit and ERP success. These findings lead to academic and practical implications on improving ERP project success via managing these key factors.
\end{abstract}

Keywords: Project Management, Enterprise Resource Planning, Adaptation, Organizational Fit 
Enhancing Organizational Fit Factors to Achieve ERP Project Success/ Hung et al.

\section{Introduction}

The relentless global competition is pressuring companies to increase international competitiveness (e.g. cycle time, cost, and inventory reduction, customer satisfaction, as well as product innovation) by constructing an adaptive and lean supply chain. The success of a competitive supply chain highly depends on the sharing of useful information among supply chain partners. Enterprise resource planning (ERP) systems are an interorganizational information system (IOS) that transcends functional and organizational boundaries. ERP has become a strategic necessity for companies competing with each other on supply chain competitiveness.

ERP implementation can impact all functional departments because of its large-scale and cross-functional nature. Integrating the diverse needs of stakeholders often lead to failures, sometimes, disasters (Ngai et al., 2008). Moreover, large-scale system implementation with time constraints (about 3 to 6 months for each module) often creates mounting pressures on team members to deliver the requirements of stakeholders on time, within budget, and with good system performance. A survey of IT managers conducted by Information Week shows that inadequate planning and management, uncontrollable scope changes, and lack of top management support are three major PM reasons causing ERP failures (Aloini et al., 2007). A further investigation of ERP success from the perspective of project management can provide insights on increasing the chance of ERP success (Hong and Kim, 2002).

A benchmarking study of ERP implementations shows that no single ERP can fit the diverse needs of different organizations because of organizational differences (Hong and Kim, 2002). When deciding on what ERP system to adopt, leading companies often carefully assess organizational fit factors (e.g. data fit, business process fit, user interface fit). These companies fully aware the importance of trade-off between ERP system customization and business process needs. Or- ganizational fit is one kind of environmental risks (e.g. the extent of changes, resource insufficiency, and task complexity) that a project manager has little control during project implementation (Sumner, 2000). If not properly managed, this environment risk may pose serious threat to the success and failure of ERP projects (Devadoss \& Pan, 2007; Pan et al., 2008). Therefore, it is imperative to study the potential influence of organizational fit factors on ERP project success. Most ERP projects consistently fail in achieving essential project management objectives; that is, delivering a project on time, within budget, meeting performance, and achieving other expected benefits. Although project complexity and long duration may partly determine ERP project success or failure, effective management practices could also be important determinants.

A study of SAP R/3 ERP projects conducted by the Standish Group International shows that ineffective project management practices (e.g. incapable team members, poor top management support, lack of training, and vendor's advising capability) could lead to ERP implement failure. The findings of this study indicate that project management practices may affect the extent of success or failure in ERP project implementations. Although previous study examined ERP system success from the organizational fit perspective, they did not incorporate project management factors into the relationships as moderating factors (Hong \& Kim, 2002). To close the knowledge gap, this paper investigates ERP system success from both PM and organizational fit perspectives and provides insights on the moderating influence of key PM factors on the relationship between organizational fit and system success.

The remaining sections will first develop a theoretical model by reviewing literatures on ERP success, organizational fit, organizational adaptation, and project management. Hypotheses will be proposed based on the model. A section of research methodology will be used to examine the rigor of data collection procedure and data analysis method. 
Enhancing Organizational Fit Factors to Achieve ERP Project Success/ Hung et al.

Data analysis results will verify our proposed hypotheses, and lead to limitations and future research. This study will be concluded with academic and practical implications.

\section{Theoretical Development}

\section{The Impact of Organizational Fit on the Success of ERP Projects}

Organizational fit is an important determinant for the success of organizations implementing ERP projects (Hong and Kim, 2002). However, every organization has unique ways of conducting business, such as corporate culture, database structure, business process, management style, and system interface design. ERP systemsintegrate an enterprise's resources across functions. ERP projects are more likely to fail if they do not fit the needs of an enterprise project failure (Basoglu et al., 2007; Pan et al., 2008). Therefore, organizational fit; that is, the alignment between ERP and organizational factors is indispensible to ERP success (Hong and Kim, 2002).

All ERP projects are unique because software customization(Zach \& Munkvold, 2012) is required to fit with specific needs of the adopting organization. As the degree of customization is increased, managing project success becomes challenging because of increased project cost and time(Devadoss \& Pan, 2007). A successful ERP project needs to be delivered on time, within budget, in scope, and with good performance (Akçaet al., 2013). Efforts on enhancing organizational fit (data fit, process fit, and user interface fit) may lead to improved system performance and develop ERP that meets with user requirements. It is imperative to minimize the influence of organizational fit factors in order to deliver project within budget, on time, and to project requirements. We therefore propose the following hypotheses:

H1: Increasing organizational fit will increase ERP project success (cost, time, performance, benefits).

\section{The Moderating Effect of Organiza- tional Adaptation Factors on the Rela-}

\section{tionship between Organizational Fit and ERP Success}

Adaptation is an important stage for achieving system infusion after a system is adopted (Kwon and Zmud, 1987). The main purpose of adaption is to customize the software for the specific organization before it is routinized and institutionalized (DeSanctis and Poole, 1994). Adaptation is particularly important for an organization to adopt a novelty or unproven system because business process and technology may not fit with each other (Pan et al., 2008). Moreover, organizational fit relates to the adoption decision made earlier in ERP project. During the implementation, organizations may engage more in system and business process adapation. An effective adaptation can increase the chance of system success (Pan et al., 2008) over time by further enhancing the positive infuence of organizational fit factors on ERP project success.

ERP is an enterprise-wide system affecting users in different functions and corporate levels. Adaptation is an indispensible part of ERP implementation because users have different preference to user-interface, working style, and system design. ERP vendors offer a spectrum of choices for varying needs of an organization, ranging from simple configuration to complex modification of complex package codes (Brehm et al., 2001). Tailoring or configuring ERP systems for specific needs of an organization can increase ERP success (Tan et al., 2012). Along with the progress of ERP projects, many unanticipated issues (e.g. user resistance, deep learning curve of users, external environment changes) may arise. The prevalence of these issues may undermine the positive influence of organizational fit on project success. The ability of an organization to adapt itself to these unanticipated issues may further enhance the positive influence of organizational fit on project success (Markus and Tannis, 2000; Hong and Kim, 2002).We therefore propose the following hypothese:

H2: System adaptation has a moderating effect on the relationship between organiza- 
Enhancing Organizational Fit Factors to Achieve ERP Project Success/ Hung et al.

tional fit and ERP project success (cost, time, performance, benefits).

ERP has many default features designed to standardize the operational procedure based on the best practice. This inherent design often creates incompatibility with the existing business process of the adopting organization. Therefore, a certain degree of business process adaptation is imperative to achieve ERP success. For instance, an effective ERP system can embed optional functions and business processes so that an organization can pick and choose them to achieve the alignment between system and organization (Vandaie, 2008).

Business process adaptation often involves business process reengineering (BPR) to analyze, design, and streamline business tasks performed to achieve a defined business outcome (Grover et al., 1995). Successful business process adaptation enabled by ERP can lead to operational efficiency and competitive advantages (Bhattacharya et al., 2010). Therefore, it is important for an organization to continue efforts in tailoring its business process to achieve the synergy of ERP utilization.

In the early project phase, the relationship between organizatoinal fit and project outcomes may be less suspetible to the influence of business process change. However, an organiation may need to adjust its business process in order to cope with enviromental changes afte the project is implemented. Therefore, the business process adaptation may have a moderating effect on the relationship between organizational fit and ERP project success. We therefore propose the following hypothesis:

H3: Business process adaptation has a moderating effect on the relationship between organizational fit and ERP project success (cost, time, performance, benefits).

Change is the only constant in an organization. ERP is an important change agent causing changes to the existing organizational structure and business process. If organizational changes are not properly managed, employees will begin to resist and even resent ERP project implementations. The absence of active user participation can ultimately lead to project failure.

Organizational resistance is more difficult to address than technical challenges in change management. The management is the process of making decisions on behalf of corporate employees in order to satisfy corporate objectives and employees' needs. From the perspective of users, they are concerned with personal interests (e.g. power, resources, and time) and whether ERP will threaten them. When employees sense the fear of losing their personal interests, they will begin the resistance (Robbins and Johnson, 1993). In the early stage of ERP implementation, users may not aware the potenital impact on their jobs. As ERP begins to show its effect (automate routine tasks, reduce human errors, streamline business process), users may become resistent to the full-scale implementation. Although organizational fit may still have positive effect on project success, the effect may be undermiend or enhanced by the adaptability of an organization to resistance. We therefore propose the following hypothese:

H4: Organizational resistance adaptation has a moderating effect on the relationship between organizational fit and ERP project success (cost, time, performance, benefits).

\section{The Moderating Effect of Key Project Management Factors on the Relation- ship between Organizational Fit and ERP Success}

This study aims to understand the moderating effect of important PM factors not fully assessed in previous ERP study emphasizing on organizational fit. These PM factors include teamwork capability, top management support, end-user training, and vendor's advising capability.

Teamwork capability is team members' ability of performing assigned responsibilities, and making coordinated and synergized actions toward achieving a common goal (Katzen- 
back and Smith, 1993). The presence of key teamwork elements is indispensible to the success of projects: common purpose, interdependence, clear roles and contributions, member satisfaction, mutual and individual accountability, empowerment, and realization of synergies (Sheard and Kakabadse, 2004). An effective ERP team is often consisted of members who are not only technical competent and understanding business process, but also has the ability to interact with others and resolve conflicts (Wang, et al., 2008). The presence of key teamwork elements is even more important for a cross-functional team as often seen in ERP project to succeed (Wang et al., 2008; Nah et al., 2003; Remus, 2007; Somers and Nelson, 2001; Umble et al., 2003). An ERP adopting firm should ensure that teamwork capability be readily available in order to help enhance the direct influence of organizational fit on ERP project success. Organizational fit may be more strongly associated with ERP project success under conditiosn of strong teamwork capability compared to conditions of weak teamwork capability. We therefore propose the following hypothese:

H5: Teamwork capability has a moderating effect on the relationship between organizational fit and ERP project success (cost, time, performance, benefits).

Top management support is indispensible for an organization to cope with the complexity of change and resource allocation (Gable, 1991). Moreover, ERP is an expensive project for most organizations because its total cost of ownership (TCO) averages about $\$ 15$ million dollars (Wailgum, 2012). Without the authorization of top management, most ERP projects will not be approved in the first place (Ngai et al., 2008). Executive participation can help improve ERP project success by resolving conflicts, tracking project status, overcoming barriers to adoption, providing resources, energizing team, and accelerating the decision-making process (Akkermans and Van Helden, 2002; Finney and Corbett, 2007). Organizational fit may be more strongly associated with ERP project success under conditions of active particiatipon of top manage- ment compared to conditions of passive participation. Hence, it is probable that top management support can help increase ERP project success by moderating (enhancing or decreasing) the influence of organizational fit factors. We therefore propose the following hypothese:

H6: Top management support has a moderating effect on the relationship between organizational fit and ERP project success (cost, time, performance, benefits).

Not having enough end-user training has been one of major causes for ERP failure (Gupta, 2000; Devadoss and Pan, 2007). ERP is complicated to use because it involves business process changes, requiring that users are equipped not only technical skills but also business knowledge. A proper training program can help end-users understand the complexity of using ERP systems and utilize them to increase personal productivity (Amoako-Gyampah and Salam, 2004). An effective training should take place in the early stage of ERP adoption because it can help lower resistance of end-users. Successful ERP projects often have about $10-15 \%$ of total budget reserved for end-user training (Umble et al., 2003). These best practices indicate that effective end-user training can potentially increase the chance of ERP project success. In other words, organizational fit may be more strongly associated with ERP project success under conditions of effective end-user training compared to conditions of ineffective end-user training. We therefore propose the following hypothese:

H7: End-user training has a moderating effect on the relationship between organizational fit and ERP project success (cost, time, performance, benefits).

Managing outsourcing partnership has been a growing ERP topic since most ERP systems are not developed in-house. For instance, subject matter expertise is one primary contributing factor for ERP project success. Many ERP projects fail because the vendor lacks of the ability to construct an enterprise system that aligns with business strategy and meets user requirements (Wang 
Enhancing Organizational Fit Factors to Achieve ERP Project Success/ Hung et al.

et al., 2007; Wang et al., 2008). As ERP grows in complexity and scope, project success relies more or less on vendor's competence in analyzing user requirements, providing training, transferring knowledge, and upgrading systems. Therefore, organizational fit may be more strongly associated with ERP project success under conditions of vendor's high advising competence compared to conditions of vendor's low advising competence.
We therefore propose the following hypothese:

H8: Vendor's advising capability has a moderating effect on the relationship between organizational fit and ERP project success (cost, time, performance, benefits).

Figure 1 is the proposed theoretical framework based on our review of literatures on ERP, organizational fit, organizational adaptation, and project management.

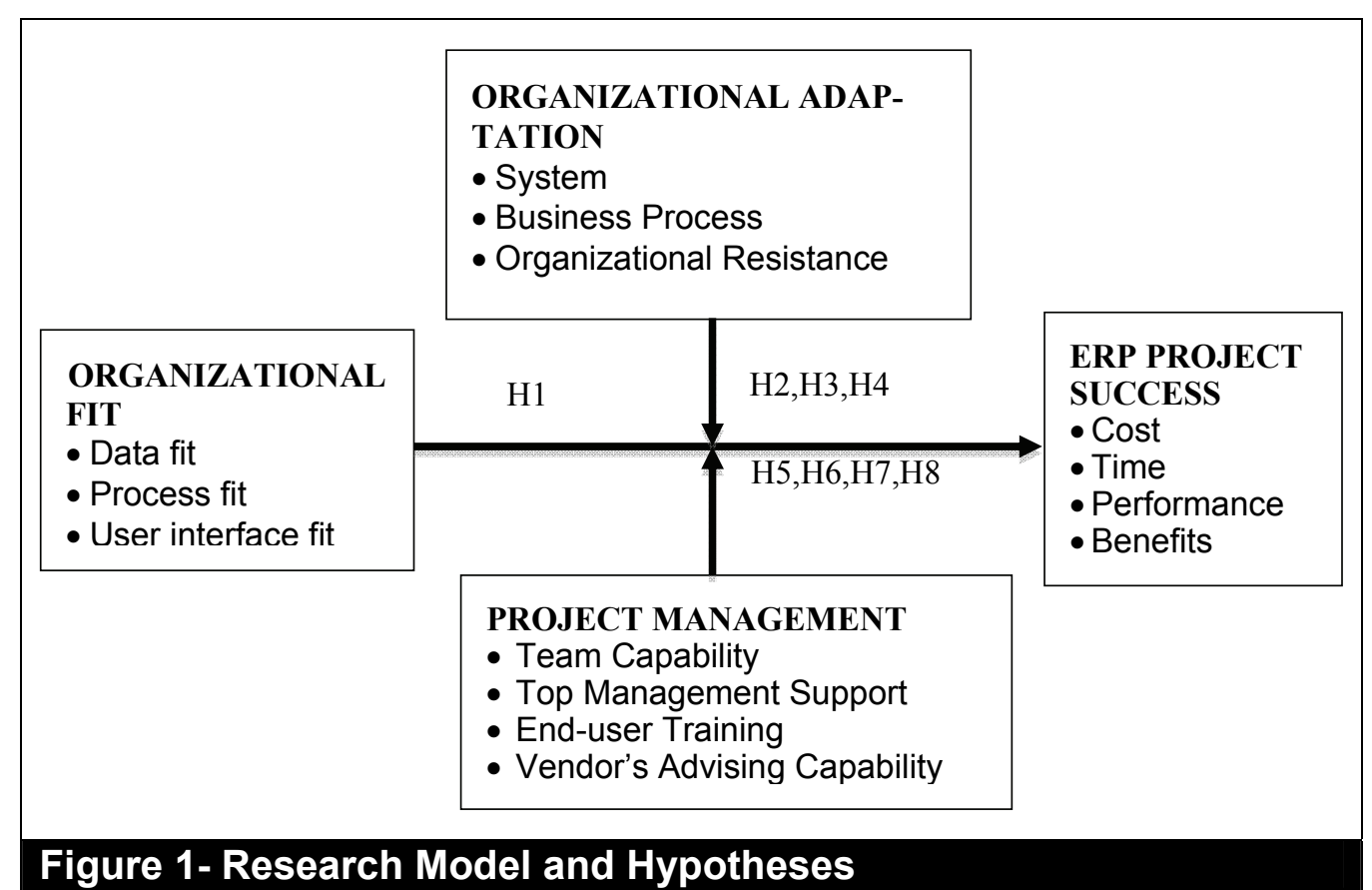

\section{Research Methodology}

To validate our proposed hypotheses, we conducted a survey with top 500 companies in Taiwan that outsourced a vendor to develop and maintain ERP systems. Information of top 500 companies provided by China Credit Information Service, Ltd. that is a largest credit information service company in Taiwan, and it provides information is reliability and validity. The mail survey was performed from April 2011 to June 2011. Total collected 129 respondents. All respondents who are adopting an in-house ERP system were excluded $(\mathrm{N}=26)$ from consideration because one of primary research questions is to learn about the potential moderating influence of vendor's advising capability on ERP success. And then, this study eliminated 34 responses who incomplete wrote questionnaire. The survey also targeted at project managers or senior managers responsible for the management of ERP projects because of the research purpose. To increase the representativeness of our sample, we invited one manager from each surveyed company to participate in the survey. Total validity sample is 69 companies.

Survey questions were designed to measure constructs in the proposed theoretical framework. All questions use a 7-point Likert scale 
ranging from 1 (Strongly Disagree) to 7 (Strongly Agree). All survey questions (Appendix 1) were modified from previous study to address research questions in this study. Two information systems faculty and five IT managers were invited to participate in a pretest and provided feedback to further improve the content validity of this survey instrument. In addition, we conducted a pilot test with ten IT managers to provide further feedback on the revised instrument with regard to the wording, syntax, and sentence construction. A final version of survey instrument was developed after the pilot test.

\section{Data Analysis Results}

\section{Demographics}

An envelope with the survey instrument and a returned stamp was mailed to 500 IT managers in top 500 companies, and follow-up phone calls were made to increase response rate. We received 129 responses with 26 of them reporting in-house development, and 34 invalid responses. A total of 69 valid responses were achieved with a $19 \%$ of response rate.

Subjects are primarily from manufacturing $(58 \%)$, retailing $(14.5 \%)$, and IT $(10 \%)$ industries. Majority of the surveyed company have more than 20 years of history $(59.4 \%)$, followed by those with 15-20 years (17.4\%). Companies with more than 1,000 to 3,000 employees $(26.1 \%)$ and more than 3,000 employees $(26.1 \%)$ are majority of samples. About $39 \%$ of the surveyed companies make the annual revenue of 0.3 to 17 billion dollars. About $90 \%$ of these companies spend less than $5 \%$ of annual budget on software, training, and other IT-related expenses. About $42 \%$ of these companies employ 6 to 20 IT professionals. As for the ERP software adopted by these companies, Oracle ERP $(39.1 \%)$ is the most popular software, followed by SAP ERP (31.9\%), and other ERP products (13\%). About $42 \%$ of ERP projects implemented lasts 6 months to 1 year. About $36.2 \%$ of companies have more than 10 years of ERP project implementationexperiences. ERP modules used by these compa- nies are primarily financial/accounting module $(97.1 \%)$, followed by data warehouse/purchasing management module $(95.7 \%)$, and sales and materials management $(88.4 \%)$. More than $42 \%$ of these companies had spent 16 to 34 million dollars and more than 160 million dollars in ERP projects.

\section{Reliability and Validity Test}

We perform Cronbach's alpha test to assess the reliability and validity of the survey questions used to measure each construct. Table 1 shows that all constructs exceed the threshold value of 0.7 , indicating a high reliability or item-to-total correlation (Hair et al. 2006). We controlled the content validity by adopting and modifying the survey instrument published in previous studyand have been reviewed by MIS scholars to assess the fitness of the questions, semantic expression, and phrasing. Before the formal test, a pretest was conducted. Content validity thus could be ensured.

Translation was involved in this study, exploratory factor analysis (EFA) was conducted. And futher analysis, MSA (measure of sampling adequacy) is smaller than 0.5 , and thus all the variables can be included in the factor analysis model.

Principal component analysis was conducted to assess the construct validity for the independent and moderating variables. KMO values for these two categories of variables are 0.813 and 0.741 , respectively, exceeding the threshold value of 0.7 and warranting factor analysis. The factor analysis shows all the items have factor loadings exceeding 0.55 (Hair et al. 2006). Therefore, no questions used to measure organizational fit, system adaptation, busines process adaptation, organizational resistance, team capability, top management support, end-user train, and vendor's advising capability were removed from the original survey instrument. 
Enhancing Organizational Fit Factors to Achieve ERP Project Success/ Hung et al.

\begin{tabular}{|c|c|c|c|c|c|c|c|}
\hline Factor & Item & $\begin{array}{l}\text { Factor } \\
\text { Loading }\end{array}$ & $\begin{array}{c}\text { Cronbach's } \\
\text { Alpha }\end{array}$ & Factor & Item & $\begin{array}{l}\text { Factor } \\
\text { Loading }\end{array}$ & $\begin{array}{c}\text { Cronbach's } \\
\text { Alpha }\end{array}$ \\
\hline \multirow[t]{2}{*}{$\begin{array}{l}\text { Organizational } \\
\text { Fit }\end{array}$} & $\begin{array}{l}\text { DF1 } \\
\text { DF2 } \\
\text { DF3 } \\
\text { DF4 }\end{array}$ & $\begin{array}{l}0.741 \\
0.773 \\
0.764 \\
0.753\end{array}$ & \multirow[t]{2}{*}{0.92} & $\begin{array}{l}\text { Team Capa- } \\
\text { bility }\end{array}$ & $\begin{array}{l}\text { TWC1 } \\
\text { TWC2 } \\
\text { TWC3 } \\
\text { TWC4 }\end{array}$ & $\begin{array}{l}0.803 \\
0.783 \\
0.711 \\
0.571\end{array}$ & 0.91 \\
\hline & $\begin{array}{l}\text { PF1 } \\
\text { PF2 } \\
\text { PF3 } \\
\text { PF4 } \\
\text { UF1 } \\
\text { UF2 } \\
\text { UF3 }\end{array}$ & $\begin{array}{l}0.574 \\
0.702 \\
0.782 \\
0.770 \\
0.696 \\
0.774 \\
0.790\end{array}$ & & $\begin{array}{l}\text { Top Man- } \\
\text { agement } \\
\text { Support }\end{array}$ & $\begin{array}{l}\text { TMS1 } \\
\text { TMS2 } \\
\text { TMS3 } \\
\text { TMS4 } \\
\text { TMS5 } \\
\text { TMS6 } \\
\text { TMS7 }\end{array}$ & $\begin{array}{l}0.774 \\
0.838 \\
0.737 \\
0.519 \\
0.621 \\
0.811 \\
0.694\end{array}$ & 0.91 \\
\hline $\begin{array}{l}\text { System Adapta- } \\
\text { tion }\end{array}$ & $\begin{array}{l}\text { SA1 } \\
\text { SA2 } \\
\text { SA3 } \\
\text { SA4 } \\
\text { SA5 } \\
\text { SA6 }\end{array}$ & $\begin{array}{l}0.841 \\
0.881 \\
0.850 \\
0.865 \\
0.797 \\
0.671\end{array}$ & 0.94 & $\begin{array}{l}\text { End-user } \\
\text { Training }\end{array}$ & $\begin{array}{l}\text { EUT1 } \\
\text { EUT2 } \\
\text { EUT3 } \\
\text { EUT4 } \\
\text { EUT5 }\end{array}$ & $\begin{array}{l}0.848 \\
0.922 \\
0.846 \\
0.821 \\
0.80\end{array}$ & 0.89 \\
\hline $\begin{array}{l}\text { Business Proc- } \\
\text { ess Adaptation }\end{array}$ & $\begin{array}{l}\text { BPA1 } \\
\text { BPA2 } \\
\text { BPA3 } \\
\text { BPA4 } \\
\text { BPA5 } \\
\end{array}$ & $\begin{array}{l}0.763 \\
0.794 \\
0.844 \\
0.826 \\
0.864 \\
\end{array}$ & 0.94 & \multirow[t]{2}{*}{$\begin{array}{l}\text { Vendor's } \\
\text { Advising } \\
\text { Capability }\end{array}$} & $\begin{array}{l}\text { VAC1 } \\
\text { VAC2 } \\
\text { VAC3 } \\
\text { VAC4 } \\
\text { VAC5 }\end{array}$ & $\begin{array}{l}0.823 \\
0.842 \\
0.885 \\
0.831 \\
0.852\end{array}$ & \multirow[t]{2}{*}{0.953} \\
\hline $\begin{array}{l}\text { Organizational } \\
\text { Resistance }\end{array}$ & $\begin{array}{l}\text { OR1 } \\
\text { OR2 } \\
\text { OR3 }\end{array}$ & $\begin{array}{l}0.638 \\
0.603 \\
0.791\end{array}$ & \multirow[t]{2}{*}{0.90} & & $\begin{array}{l}\text { VAC6 } \\
\text { VAC7 } \\
\text { VAC8 }\end{array}$ & $\begin{array}{l}0.871 \\
0.745 \\
0.726\end{array}$ & \\
\hline & $\begin{array}{l}\text { OR4 } \\
\text { OR5 }\end{array}$ & $\begin{array}{l}0.870 \\
0.869\end{array}$ & & $\begin{array}{l}\text { ERP Project } \\
\text { Sucess }\end{array}$ & $\begin{array}{l}\text { COST } \\
\text { TIME } \\
\text { PERF } \\
\text { BENE. }\end{array}$ & $\begin{array}{l}0.723 \\
0.793 \\
0.854 \\
0.807\end{array}$ & 0.802 \\
\hline
\end{tabular}

\section{Validation of Assumptions}

Normal distribution of data is an important assumption to be met before conducting the regression analysis. We drew normal probability plotsto assess whether the observations for each construct are normally distributed. An approximately straight line was plotted for all observations, indicating that all data meet the assumption of normal distribution. We further calculated the Pearson correlation coefficients to measure the degree of correlation between two variables. The analysis results showed all coefficients are less than the cut-off value of 0.8 (see Table 2), indicating that muticollinearity issues do not exist (Hair et al. 2006).

\section{Table 2 - Correlation Matrix}

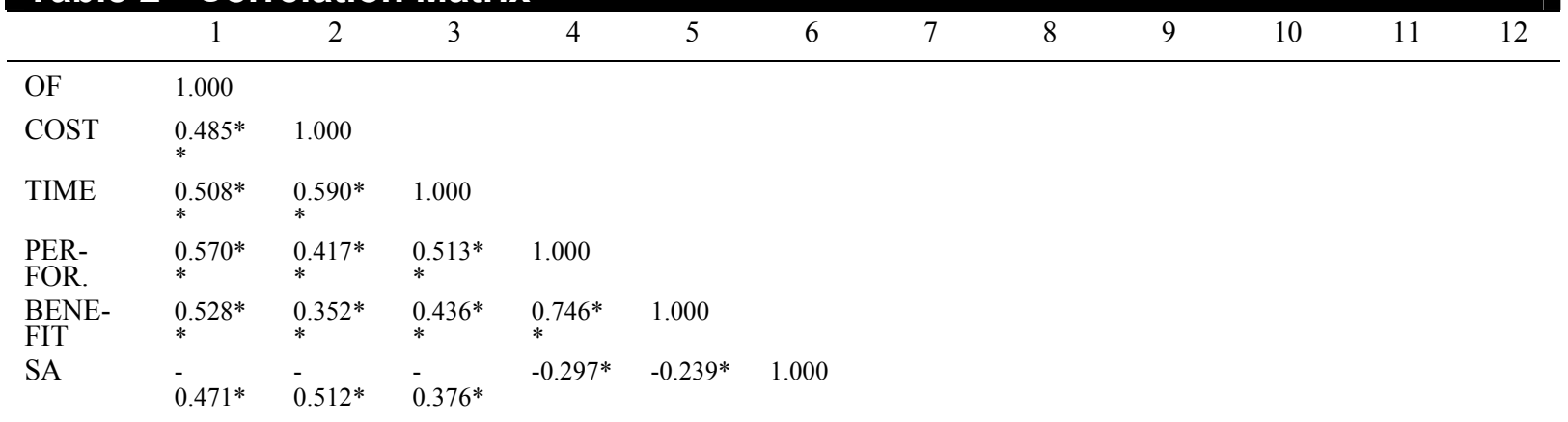




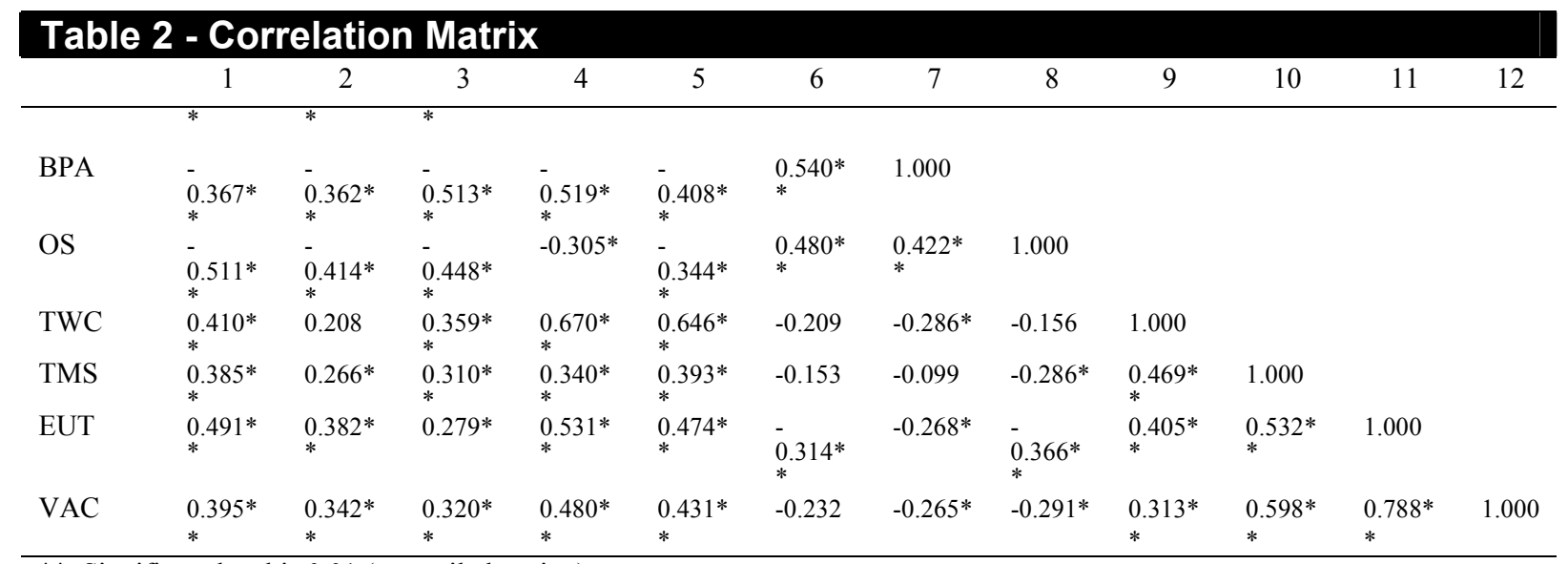

**. Significant level is 0.01 (two-tailed testing)

*. Significant level is 0.05 (two-tailed testing)

\section{Hypotheses Testing}

After removing these two concerns, we conducted a matrix analysis to measure the direct influence of organizational fit on ERP success. The results described that organizational fit has positive correlations with ERP cost management $(r=0.485)$, time management $(r=0.508)$, performance $(r=0.570)$, and benefit $(r=0.528)$. This finding indicates that increasing organizational fit for ERP projects can lead to increased cost and time management, but higher performance and satisfied customer requirements. We further conducted the moderated regression analysis to assess the effect of moderating variables on the relationship between organizational fit and ERP success.

Tables 3 show the results of moderated regression analysis for four ERP success measures: cost, time, performance, and benefit. Organizational adaptation and PM variables together have a significantly moderating effect on the relationship between organizational fit and four ERP success factors, including cost management $(\mathrm{R} 2=0.26, \mathrm{~F}=3.92$, $\mathrm{p}<0.001)$, time management $(\mathrm{R} 2=0.33$, $F=5.21, p<0.001$ ), performance management (R2=0.40, $F=6.57, \quad p<0.001$ ), and benefit management $(R 2=0.30, F=4.64, p<0$

A closer examination of the moderating effect for each variable shows that teamwork capability $(p=0.039<0.05)$ and vendor's advising capability $(p=0.091<0.1)$ have positive moderating effect, indicating that these two PM tasks can further enhance the influence of organizational fit on ERP project cost management. On the other hand, top management support $(p=0.068<0.10)$ and end-user training $(p=0.054<0.1)$ have negative moderating effect, indicating that these two PM tasks can lessen the influence of organizational fit on ERP project cost management. As for project time management, system adaptation $(p=0.084<0.05)$ and end-user training $(p=0.006<0.01)$ have negative moderating effect, indicating that these two factors will lessen the influence of organizational fit on ERP project time management. Vendor's advising capability $(p=0.029<0.5)$ has positive moderating effect, indicating that the PM task can enhance the influence of organizational fit on project time management.

To improve project performance, system adaptation $(p=0.002<0.01)$, and teamwork capability $(p=0.029<0.5)$ have negative moderating effect, indicating that these two factors can lessen the direct influence of organizational fit on project performance. Business process adaptation $(p=0.017<0.05)$ has positive moderating effect, indicating that the factor can enhance the direct influence of organizational fit on project performance. To help achieve project benefit, business process adaptation $(p=0.076<0.10)$ has positive moderating effect, indicating that the factor can enhance the influence of organizational fit on project benefit. Teamwork capability $(p=0.088<0.10)$ has negative moderating effect, indicating that the PM task can lessen the influence of organizational fit on project benefit. 
Enhancing Organizational Fit Factors to Achieve ERP Project Success/ Hung et al.

Table 3 - Effect of Moderating Variables on the Relationship between Organizational Fit and ERP Project Success

\begin{tabular}{|c|c|c|c|c|c|c|c|c|c|c|c|c|}
\hline \multirow{3}{*}{$\begin{array}{l}\text { Independent } \\
\text { I Moderating } \\
\text { Variables }\end{array}$} & \multicolumn{12}{|c|}{ Dependent Variable } \\
\hline & \multicolumn{3}{|c|}{$\begin{array}{c}\text { Cost Management } \\
R^{2}=0.26 \\
\left(F=3.92, p=0.000^{* * *}\right)\end{array}$} & \multicolumn{3}{|c|}{$\begin{array}{l}\text { Time Management } \\
R^{2}=0.33 \\
\left(F=5.21, p=0.000^{* * *}\right)\end{array}$} & \multicolumn{3}{|c|}{$\begin{array}{c}\text { Performance } \\
R^{2}=0.40 \\
\left(F=6.57, p=0.000^{* * *}\right)\end{array}$} & \multicolumn{3}{|c|}{$\begin{array}{c}\text { Benefits } \\
R^{2}=0.30 \\
\left(F=4.64, p=0.000^{* * *}\right)\end{array}$} \\
\hline & $\beta$ & $t$ & $p$ & $\beta$ & $t$ & $p$ & $\beta$ & $t$ & $p$ & $\beta$ & $t$ & $p$ \\
\hline OF & 0.24 & 0.43 & 0.672 & -0.19 & -0.36 & 0.721 & -0.79 & -1.56 & 0.123 & -0.50 & -0.92 & 0.361 \\
\hline $\mathrm{OF} * \mathrm{SA}$ & -0.07 & -0.43 & 0.669 & -0.28 & -1.76 & $0.084^{*}$ & -0.49 & -3.26 & $0.002^{* * *}$ & -0.23 & -1.40 & 0.166 \\
\hline $\mathrm{OF}{ }^{*} \mathrm{BPA}$ & 0.05 & 0.12 & 0.908 & 0.57 & 1.40 & 0.166 & 0.95 & 2.47 & $0.017^{* *}$ & 0.75 & 1.80 & $0.076^{*}$ \\
\hline $\mathrm{OF} * \mathrm{OR}$ & 0.20 & 0.43 & 0.670 & 0.10 & 0.23 & 0.817 & 0.41 & 0.97 & 0.339 & 0.28 & 0.63 & 0.534 \\
\hline OF * TWC & 0.26 & 2.11 & $0.039^{* *}$ & 0.06 & 0.52 & 0.605 & -0.25 & -2.24 & $0.029^{* *}$ & -0.21 & -1.74 & $0.088^{*}$ \\
\hline $\mathrm{OF}{ }^{*} \mathrm{TMS}$ & -0.34 & -1.86 & $0.068^{*}$ & -0.49 & -2.86 & $0.006^{\star * *}$ & 0.19 & 1.16 & 0.249 & 0.08 & 0.46 & 0.649 \\
\hline OF ${ }^{*}$ EUT & -0.34 & -1.96 & $0.054^{*}$ & -0.24 & -1.46 & 0.149 & 0.08 & 0.53 & 0.599 & 0.05 & 0.31 & 0.757 \\
\hline $\mathrm{OF}{ }^{*} \mathrm{VAC}$ & 0.36 & 1.72 & $0.091^{*}$ & 0.44 & 2.24 & $0.029^{*}$ & -0.28 & -1.49 & 0.143 & -0.19 & -0.97 & 0.339 \\
\hline
\end{tabular}

Table 4 summarizes all hypothesis results. Organizational fit has a significant positive influence on all ERP project success measures. Hypothesis $\mathrm{H} 1$ is supported. Moderating factors vary with their influence on different ERP project success measures by interacting with organizational fit factors. $\mathrm{H} 2$ is partially supported, indicating that system adaptation has positive moderating effect on ERP project time management and performance. In other words, system adaptation can help enhance the influence of organizational fit on managing projects on time and improving performance over project duration. However, system adaptation has no interaction effect with organizational fit oncost management and benefit. $\mathrm{H} 3$ is partially supported, indicating that business process adaptation has positive moderating effect on performance and benefit. In contrast, the degree of correlation between organization needs in data, process, and user interface, and the ability to control time and cost will not be changed despite of efforts and time spent in customizing business processes. Hypothesis $\mathrm{H} 4$ is not supported, regardless of ERP project success measures. This finding indicates that organizational resistance has no interaction effect with organizational fit on ERP project success measures. $\mathrm{H} 5$ is partially supported, indicating that teamwork capability has moderating effect on cost (positive), performance and benefit (negative) management. In contrast, teamwork capabiltiy has no interaction effect with organizational fit on delivering projects on time over project duration. $\mathrm{H} 6$ is partially supported, indicating that top management support has moderating effect (negative) on cost and time management. In contrast, top management support has no interaction effect with organizational fit on performance and benefits. $\mathrm{H} 7$ is partially supported, indicating that end-user training has moderating effect (negative) on cost management. In contrast, end-user training has no interaction effect with organizational fit on time, performance and benefit. $\mathrm{H} 8$ is partially supported, indicating that vendor's advising capability has positive moderating effect on cost and time management. However, the ability has no interaction effect with organizational fit on performance and benefit. 


\begin{tabular}{|c|c|c|c|c|}
\hline \multirow{2}{*}{$\begin{array}{l}\text { Independent / Moderat- } \\
\text { ing Variables }\end{array}$} & \multicolumn{4}{|c|}{ ERP Project Success } \\
\hline & $\begin{array}{c}\text { Cost Man- } \\
\text { agement }\end{array}$ & $\begin{array}{c}\text { Time Man- } \\
\text { agement }\end{array}$ & Performance & Benefit \\
\hline $\begin{array}{l}\text { OF } \\
(\mathrm{H} 1)\end{array}$ & 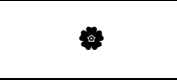 & 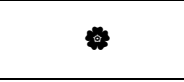 & - & - \\
\hline $\mathrm{OF}{ }^{*} \mathrm{SA}(\mathrm{H} 2)$ & $\mathrm{O}$ & 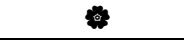 & 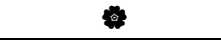 & 0 \\
\hline $\mathrm{OF}^{*} \mathrm{BPA}(\mathrm{H} 3)$ & $\mathrm{O}$ & $\mathrm{O}$ & 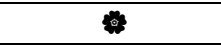 & 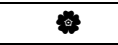 \\
\hline $\mathrm{OF}^{*} \mathrm{OR}(\mathrm{H} 4)$ & $\mathrm{O}$ & $\mathrm{O}$ & 0 & 0 \\
\hline OF * TWC (H5) & \% & $\mathrm{O}$ & 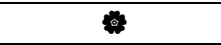 & 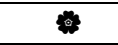 \\
\hline OF * TMS (H6) & 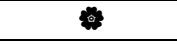 & 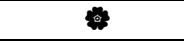 & $\mathrm{O}$ & $\mathrm{O}$ \\
\hline $\begin{array}{l}\text { OF * EUT } \\
(\mathrm{H} 7)\end{array}$ & 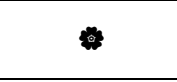 & 0 & 0 & 0 \\
\hline $\mathrm{OF}^{*} \mathrm{VAC}(\mathrm{H} 8)$ & 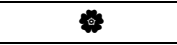 & 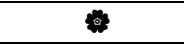 & $\mathrm{O}$ & 0 \\
\hline
\end{tabular}

\section{Discussion}

Organizational fit has a direct, positive influence on ERP project cost, time management, performance and benefit. Increasing the organizational fit of the adopting company for ERP projects may increase project cost and time management, but increase system performance, and meet the project benefit. Performance $(\beta=0.570)$ receives the largest impact from organizational fit, followed by benefit $(\beta=0.528)$, time $(\beta=0.508)$, and cost management $(\beta=0.485)$. When managing an ERP project, a project manager needs to improve its degree of fit for data, business process, and user interface because these factors can lead to project success in performance and benefit. However, too much of efforts spent on organizational fit may increase project cost and miss the deadline.

The adopting organization needs to aware that the main effect between organizational fit and ERP project success (deliveirng project on time, within budget, within scope, and having expected benefits) may also subject to the positive or negative moderating influence of organizational adaptation or project management factors. As for organizational adaptation, our study shows that although increasing efforts in system adaptation may improve system performance the adopting organization may want to extend the deadline since it may require extra time to complete an ERP project. In contrast, an organization may want to continuously improve business process adaptation because doing so can enhance system performance and meet user requirements.

As for project management factors, organizational resistance does not exhibit any moderating effect on project success. More than $58 \%$ the surveyed companies have adopted ERP more than one year and $36.2 \%$ of all companies have more than 10 years of ERP experiences. Organizational resistance often occurs in the early adoption stage of a project. Long experiences of adopting ERP projects may undermine the potential influence of organizational resistance. Teamwork capability may cause the scope creeping and project performance issues because of potential adds-on to the original project benefit during the organizational fitting process. This also explains why project cost can be further increased with improved teamwork capability. Top management support has been advocated as an important element for project success because it can help project team understand the big picture, focus on tasks aligned with strategic goals, and allocate resources. Our finding further corroborates with the importance of top management support with regard to better project cost and time management in the process of adjusting organizational business process for ERP projects. End-user training can also help the adopting company achieve better project cost management in addition to the general un- 
Enhancing Organizational Fit Factors to Achieve ERP Project Success/ Hung et al.

derstanding of increasing buy-ins for ERP projects. After receiving proper training, endusers can improve their personal productivity without being constantly disrupted for lack of understanding or skills of using ERP. On the other hand, asking for outside helps often cost more money and time. This finding corroborate with the general idea that increased reliance on vendor's advising capability can lead to increased project cost and time management.

\section{Academic and Practical Implications}

Previous study shows that organizational fit, consisting of data, business process, and user interface, are critical to ERP project success. In addition, organizational adaptation, consisting of system, business process, and organizational resistance, plays an important moderating role for the relationships between organizational fit and ERP project success. However, these studies did not consider the moderating role of project management factors, and measure ERP success from the PM perspective. To provide insights on the potential moderating influence of key project management factors, this study include five key project management factors in Hong and Kim's (2002) study and measure ERP success with four variables:cost, time, performance, and benefit. Based on Baron and Kenny's (1986) study, a moderated regression analysis was conducted to assess the presence of these moderating factors. The findings of this study extend the current literature on organizational fit for ERP projects and ascertain the importance of key project management factors.

Organizational adaptation and project management factors have varying moderating effect on the relationship between organizational fit and ERP project success. These findings indicate that the adopting company needs to emphasize on different moderating factors in order to achieve different measures of ERP project success. To achieve ERP project success in cost management, the adopting company can try to provide top management support and end-user training. On other hand, to control the increase of cost caused by the improved organizational fit for ERP projects the adopting organization should not emphasize too much on teamwork capability and vendor's advising capability. To achieve ERP project success in time management, the adopting company should emphasize on improving system adaptation and providing top management support. On the other hand, to control the increase of time caused by the organizational fit should not rely too much on vendor's advising capability. To achieve performance, the adopting company can focus on addressing business process adaptation because it can enhance the influence of organizational fit on system performance. On the other hand, too much emphasis on system adaptation and teamwork capability may undermine the direct influence of organizational fit on system performance. Therefore, these two forces should be properly managed. To meet project benefit or user requirements, the adopting company should emphasize on business process adaptation, rather than teamwork capability because the former is more effective at enhancing the direct influence of organizational fit on meeting project benefit.

\section{Limitations and Research Direction}

To increase generalizability, this study surveyed only one IT manager or senior manager from each company. However, ERP is an enterprise-wide system, involving people from different functional departments. Surveying with one person may not be able present a complete picture of ERP projects undertaken by different stakeholders vested with conflict interests in each company. In addition, the findings of this study cannot be generalized to small- and medium-sized enterprises because all surveyed companies are top 500 countries in Taiwan. The potential influence of company size may lead to different findings. However, we cannot assess its potential influence on the findings of this study. Another major limitation is that manufacturing sector accounts for the largest share of the sample, which may confound the findings of this study. Future study may want to equal the sample size from different industries to better control the potential influence of the industry sector. 
ERP projects last for long time and involve different people and resources at different stages of implementation. The survey methodology adopted in this study may not be able to capture the rich information of project management activities happening at each stage of the project life cycle. This study also did not survey companies in different countries or international companies operating across borders. Using Taiwanese companies alone in the survey may limit the applicability of the finding to companies in other countries.

This study confirms the importance of organizational fit as an independent variable, as well as of organizational adaptation and project management factors as moderating variables for the dependent variable of project management success. Although not all factors exhibit significant influence, future research may want to replicate this study with other factors, such as risk management and user requirement analysis, that may be relevant to ERP project success. About $27.37 \%$ of respondents reported that they developed ERP in-house; most of these companies were in the transportation and service industry sectors. Since this study does not consider these companies developing ERP in-house, future research may want to take them into consideration. All respondents are IT managers or

\section{References}

Akça, Y., Esen, S.,\&Özer, G. (2013). "The Effects of Education on Enterprise Resource Planninglmplementation Success and Perceived Organizational Performance,"International Business Research, 6(5), pp. 168-179.

Akkermans, H., \& van Helden, K. (2002). "Vicious and Virtuous Cycles in ERP Implementation: a Case Study of Interrelations between Critical Success Factors," European Journal of Information Systems, 11(1), pp. 35-46.

Aloini, D., Dulmin, R., \& Mininno, V. (2007). "Risk Management in ERP Project Introduction: Review of the Literature," Information \& Management, 44(6), pp. 547-567. senior managers. Different stakeholders, such as vendors, administrator, user and functional managers, are involved throughout the ERP project life cycle. These stakeholders have different concerns. A survey or case study with different stakeholders may help present a holistic picture of critical factors and challenges to ERP project success.

\section{Conclusion}

Although organizational fit has a direct influence on ERP project success, the relationship is subject to the moderating effect of organizational adaptation and project management factors. ERP project success measures examined in this study include project cost, time, performance, and benefit. Organizational adaptation factors include system adaptation and business process adaptation. Project management factors include strong teamwork, top management support, enduser training and vendor's advising capability. The adopting company should consider enforcing or lessening the influence of these moderating factors on achieving ERP project success. This study offers insights on the importance of examining ERP project success from the project management perspective.

Amoako-Gyampah, K., \& Salam, A. F. (2004). "An Extension of the Technology Acceptance Model in an ERP Implementation Environment," Information \& Management, 41(6), pp. 731-745.

Baron, R. M., \& Kenny, D. A. (1986). "The Moderator-Mediator Variable Distinction in Social Psychological Research: Conceptual, Strategic, and Statistical Considerations," Journal of Personality and Social Psychology, 51(6), pp. 1173-1182.

Basoglu, N., Daim, T., \& Kerimoglu, O. (2007). "Organizational Adoption of Enterprise Resource Planning Systems: A Conceptual Framework," The Journal of 
Enhancing Organizational Fit Factors to Achieve ERP Project Success/ Hung et al.

High Technology Management Research, 18(1), pp. 73-97.

Bhattacharya, P. J., Seddon, P. B., \& Scheepers, R. (2010). "Enabling Strategic Transformations with Enterprise Systems: Beyond Operational Efficiency,"ICIS 2010 Proceedings, pp.55.

Brehm, L., Heinzl, A. and Markus, M.L. (2001). "Tailoring ERP Systems: a Spectrum of Choices and Their Implications," Proceeding of the 34th Annual Hawaii International Conference on System Sciences (HICSS), Maui, Hawaii.

DeSanctis, G., \&Poole, M. S. (1994). "Capturing the Complexity in Advanced Technology Use: Adaptive Structuration theory," Organization Science, 5(2), pp. 121-147.

Devadoss, P. and Pan, S L. (2007) "Enterprise Systems Use: Towards a Structurational Analysis of Enterprise Systems-induced Organizational Transformation". Communications of the AIS, 19(1), pp. 352-385.

Finney, S., \& Corbett, M. (2007). "ERP Implementation: a Compilation and Analysis of Critical Success Factors," Business Process Management Journal, 13(3), pp. 329-347.

Gable, G. G. (1991). "Consultant Engagement for Computer System Selection: a Pro-active Client Role in Small Businesses," Information \& Management, 20(2), pp.83-93.

Grover, V., Jeong, S. R., Kettinger., J., W., \& Teng, J. T. C. (1995). "The Implementation of Business Process Reengineering," Journal of MIS, 12(1), pp. 109-144.

Gupta, A. (2000). "EnterpriseResource Planning: The Emerging Organizational Value Systems," Industrial Management \& Data Systems, 100(3), pp. 114-118.
Hair, J. F., Anderson, R. E., Tatham, R. L., \& Black, W. C. (2006). Multivariate Data Analysis, 6th, New Jersey.

Hong, K.-K., \& Kim, Y.-G. (2002). "The Critical Success Factors for ERP Implementation: an Organizational Fit Perspective," Information \& Management, 40(1), pp. 25-40.

Jurison, J. (1999). "Software Project Management: The Manager's View," Communications of AIS, 2(3).

Katzenbach, J. R., \& Smith, D. K. (1993). The Wisdom of Team : Creating the HighPerformance Organization. New York: McGraw-Hill.

Kwon, T. H., \& Zmud, R. W. (1987). Unifying the Fragmented Models of Information Systems Implementation, Critical Issues in Information Systems Research, John Wiley \& Sons, Inc., New York.

Markus, M.L., Tanis, C. (2000). "The Enterprise System Experience: From Adoption to Success,"in Zmud, R. (Ed.), Framing the Domains of IT Management: Projecting the Future through the Past. Pinnaflex Educational Resources Inc, Cincinnati.

Nah, F. F.-H., Zuckweiler, K. M., \& Lau, J. L.S. (2003). "ERP Implementation: Chief Information Officers' Perceptions of Critical Success Factors," International Journal of HumanComputer Interaction, 16(1), pp. 5-22.

Ngai, E. W. T., Law, C. C. H., \& Wat, F. K. T. (2008). "Examining the Critical Success Factors in the Adoption of Enterprise Resource Planning," Computers in Industry, 59(6), pp. 548-564.

Pan, G. Hackney, R., \& Pan, S. L. (2008) "Information Systems Implementation Failure: Insights from PRISM". International Journal of Information Management, 28(4): 1-27.

Remus, U. (2007). "Critical Success Factors for Implementing Enterprise Portals: a 
Comparison with ERP Implementations," Business Process Management Journal, 13(4), pp. 538-552.

Robbins, S. P., \& Johnson, H. J. (1993). Organization Behavior. Englewood Cliffs, New York: Prentice-Hall.

Sheard, A.G., and Kakabadse, A.P. (2004). "A Process Perspective on Leadership and Team Development," The Journal of Management, 23(1), pp.7-106.

Somers, T., \& Nelson, K. (2001). "The Impact of Critical Success Factors Across the Stages of Enterprise Resource Planning Implementations," Proceedings of Hawaii International Conference on System Sciences.

Tan, S. Y., Rosnah, I., \&Wai, P. W. (2012). "ERP Misfit-Reduction Strategies: A Moderated Model of System Modification and Organizational Adaptation," Journal of Global Information Management, 21(1), pp. 59-81.

Umble, E. J., Haft, R. R., \& Umble, M. M. (2003). "EnterpriseResource Planning: Implementation Procedures and Critical Success Factors," European Journal of Operational Research, 146(2), pp. 241-257.
Vandaie, R. (2008). "The Role of Organizational Knowledge Management in Successful ERP Implementation Projects," Knowledge-Based Systems, 21(8), pp. 920-926.

Wailgum, T. (2012). "ERP Definition and Solutions, $\quad \mathrm{ClO}$,"Retrieved fromhttp://www.cio.com/article/40323/ ERP_Definition and Solutions?page $=3$ on Feb. 12, 2012.

Wang, E. T. G., Lin, C. C.-L., Jiang, J. J., \& Klein, G. (2007). "Improving Enterprise Resource Planning (ERP) Fit to Organizational Process through Knowledge Transfer," International Journal of Information Management, 27(3), pp. 200-212.

Wang, E. T. G., Shih, S.-P., Jiang, J. J., \& Klein, G. (2008). "The Consistency among Facilitating Factors and ERP Implementation Success: A Holistic View of Fit," Journal of Systems and Software, 81(9), pp. 1609-1621.

Zach, O., \&Munkvold, B. E., (2012) "Identifying reasons for ERP system customization in SMEs: a multiple case study", Journal of Enterprise Information Management, 25(5), pp.462 - 478. 


\section{Appendix 1: Survey Instrument}

\begin{tabular}{|c|c|c|c|c|}
\hline Factor & $\begin{array}{l}\text { Operational Defini- } \\
\text { tion }\end{array}$ & $\begin{array}{l}\# \text { of } \\
\text { Item }\end{array}$ & Reference & Items \\
\hline $\begin{array}{l}\text { Organizational } \\
\text { Fit }\end{array}$ & $\begin{array}{l}\text { "The degree of } \\
\text { alignment between } \\
\text { ERP model and or- } \\
\text { ganization needs in } \\
\text { terms of data, process } \\
\text { and user inter- } \\
\text { face(p.30)." }\end{array}$ & 11 & $\begin{array}{l}\text { Hong and Kim } \\
\text { (2002) }\end{array}$ & $\begin{array}{l}\text { 1. The processes built in ERP meet } \\
\text { all needs required from organ- } \\
\text { izational processes. } \\
\text { 2. The processes fow built in ERP } \\
\text { correspond to fow of organiza- } \\
\text { tional processes. } \\
\text { 3. The processes built in ERP ac- } \\
\text { commodate the change required } \\
\text { from organizational processes. } \\
\text { 4. The processes built in ERP cor- } \\
\text { respond to the business practices } \\
\text { of our company. } \\
\text { 5. The name and meaning of the } \\
\text { ERP data items correspond to } \\
\text { those of the documents used in } \\
\text { our company. } \\
\text { 6. The form and format data items } \\
\text { of the ERP correspond to those } \\
\text { of the documents used in our } \\
\text { company. } \\
\text { 7. The output data items of the } \\
\text { ERP correspond to those of the } \\
\text { documents used in our company. } \\
\text { 8. The input data items of the ERP } \\
\text { correspond to those of the doc- } \\
\text { uments used in our company. } \\
\text { 9. User interface structures of the } \\
\text { ERP is well designed to the } \\
\text { work structure required for con- } \\
\text { ducting business in our com- } \\
\text { pany. } \\
\text { 10. User interface of the ERP is } \\
\text { well designed to the user capa- } \\
\text { bilities of our company. } \\
\text { 11. User interface of the ERP is } \\
\text { well designed to the business } \\
\text { needs of our company. }\end{array}$ \\
\hline $\begin{array}{l}\text { System Adap- } \\
\text { tation }\end{array}$ & $\begin{array}{l}\text { "The extent of efforts } \\
\text { and time spending in } \\
\text { ERP alteration to } \\
\text { align with organiza- } \\
\text { tional process needs } \\
\text { except for ERP cus- } \\
\text { tomization (p.30)." }\end{array}$ & 6 & $\begin{array}{l}\text { Hong and Kim } \\
\text { (2002) }\end{array}$ & $\begin{array}{l}\text { 1. Significant time and effort have } \\
\text { been required to alter ERP data } \\
\text { items to align with our organiza- } \\
\text { tional process needs. } \\
\text { 2. Significant time and effort have } \\
\text { been required to append new } \\
\text { ERP data items to align with our } \\
\text { organizational process needs. } \\
\text { 3. Significant time and effort have }\end{array}$ \\
\hline
\end{tabular}




\begin{tabular}{|c|c|c|c|c|}
\hline Factor & $\begin{array}{l}\text { Operational Defini- } \\
\text { tion }\end{array}$ & $\begin{array}{l}\text { \# of } \\
\text { Item }\end{array}$ & Reference & Items \\
\hline & & & & $\begin{array}{l}\text { been required to alter ERP proc- } \\
\text { esses to align with our organiza- } \\
\text { tional process needs. } \\
\text { 4. Significant time and effort have } \\
\text { been required to append new ERP } \\
\text { processes to align with our organ- } \\
\text { izational process needs. } \\
\text { 5. Significant time and effort have } \\
\text { been required to alter ERP in- } \\
\text { put/output screens to align with our } \\
\text { organizational process needs. } \\
6 \text {. Significant time and effort have } \\
\text { been required to alter ERP reports } \\
\text { to align with our organizational } \\
\text { process needs. }\end{array}$ \\
\hline $\begin{array}{l}\text { Process Adap- } \\
\text { tation }\end{array}$ & $\begin{array}{l}\text { "The extent of effort } \\
\text { and time spending in } \\
\text { process change to } \\
\text { align with ERP } \\
\text { (p.30)." }\end{array}$ & 5 & $\begin{array}{l}\text { Hong and Kim } \\
(2002)\end{array}$ & $\begin{array}{l}\text { 1. Significant time and effort have } \\
\text { been required to alter elementary } \\
\text { processes to align with the ERP. } \\
\text { 2. Significant time and effort have } \\
\text { been required to alter our process } \\
\text { flows to align with the ERP. } \\
\text { 3. Significant time and effort have } \\
\text { been required to standardize our } \\
\text { organizational processes to align } \\
\text { with the ERP. } \\
\text { 4. Significant time and effort have } \\
\text { been requiredto integrate our re- } \\
\text { dundant organizational processes } \\
\text { to align with the ERP. } \\
5 \text {. Significant time and effort have } \\
\text { been required to alter our docu- } \\
\text { ment and data elements to align } \\
\text { with the ERP. }\end{array}$ \\
\hline $\begin{array}{l}\text { Organization } \\
\text { resistance }\end{array}$ & $\begin{array}{l}\text { "The strength of neg- } \\
\text { ative organizational } \\
\text { response to ERP im- } \\
\text { plementation (p.30)." }\end{array}$ & 5 & $\begin{array}{l}\text { Hong and Kim } \\
(2002)\end{array}$ & $\begin{array}{l}\text { 1. There have been many users } \\
\text { resisting the ERP implementa- } \\
\text { tion. } \\
\text { 2. There have been many cases } \\
\text { blaming occurrence of business } \\
\text { problem upon ERP. } \\
\text { 3. There have been many cases in } \\
\text { which users persist traditional } \\
\text { business practice even though } \\
\text { ERP change the way of conduct- } \\
\text { ing business. } \\
\text { 4. There have been many cases in } \\
\text { which user departments did not } \\
\text { reply to the business request of } \\
\text { the ERP project team. } \\
\text { 5. There have been many people }\end{array}$ \\
\hline
\end{tabular}


Enhancing Organizational Fit Factors to Achieve ERP Project Success/ Hung et al.

\begin{tabular}{|c|c|c|c|c|}
\hline Factor & $\begin{array}{l}\text { Operational Defini- } \\
\text { tion }\end{array}$ & $\begin{array}{l}\text { \# of } \\
\text { Item }\end{array}$ & Reference & Items \\
\hline & & & & wishing ERP to fail. \\
\hline $\begin{array}{l}\text { End-user } \\
\text { Training }\end{array}$ & $\begin{array}{l}\text { "Training provides } \\
\text { managers with } \\
\text { amechanism to dis- } \\
\text { seminate useful and } \\
\text { pertinent informa- } \\
\text { tionabout the ERP } \\
\text { system and how it } \\
\text { fits in withthe exist- } \\
\text { ing and proposed } \\
\text { system." }\end{array}$ & 5 & $\begin{array}{l}\text { Amoako- } \\
\text { Gyampah and } \\
\text { Salam (2004); }\end{array}$ & $\begin{array}{l}\text { 1. The kind of training provided to } \\
\text { me was complete } \\
\text { 2.My level of understanding was } \\
\text { substantially improved after go- } \\
\text { ing through the training program } \\
\text { 3. The training gave me confidence } \\
\text { in the NEW system } \\
\text { 4. The training was of adequate } \\
\text { length and detail } \\
\text { 5.The trainers were knowledgeable } \\
\text { and aided me in my understand- } \\
\text { ing of the system }\end{array}$ \\
\hline $\begin{array}{l}\text { Teamwork Ca- } \\
\text { pability }\end{array}$ & & 4 & $\begin{array}{l}\text { Saari- } \\
\text { nen(1996) }\end{array}$ & $\begin{array}{l}\text { 1.IS knowledge } \\
\text { 2.Business knowledge } \\
\text { 3.Communicatiosnk ills } \\
\text { 4.Commitment }\end{array}$ \\
\hline $\begin{array}{l}\text { Vendor's Ad- } \\
\text { vising Capabil- } \\
\text { ity }\end{array}$ & & 8 & $\begin{array}{l}\text { Roberts et } \\
\text { al.(2001) }\end{array}$ & $\begin{array}{l}\text { 1.Providing the message that } \\
\text { methodology implementation } \\
\text { involves a cultural change } \\
\text { 2.Involved in each of the various } \\
\text { techniques used methodology } \\
\text { 3.Providing expertise in executing } \\
\text { the transition to the new meth- } \\
\text { odology } \\
\text { 4.Providing evidence of the value } \\
\text { of the methodology } \\
\text { 5.Providing a complete under- } \\
\text { standing in the new methodol- } \\
\text { ogy } \\
\text { 6.Contributing expertise and ex- } \\
\text { perience in using the methodol- } \\
\text { ogy } \\
\text { 7.Providing knowledge on how the } \\
\text { new methodology will affect } \\
\text { roles and responsibilities for } \\
\text { personnel involved } \\
\text { 8. Returning at a later date to insure } \\
\text { changes to the development pro- } \\
\text { cess are properly completed }\end{array}$ \\
\hline $\begin{array}{l}\text { Top Manage- } \\
\text { ment Support }\end{array}$ & & 7 & $\begin{array}{l}\text { Lee and } \\
\text { Kim(1992) }\end{array}$ & $\begin{array}{l}\text { 1. Top manager tries to take part in } \\
\text { deciding in what order the ERP- } \\
\text { should be implemented } \\
\text { 2. Top manager tries to encourage } \\
\text { the user departments to use ERP } \\
\text { 3. Top manager is favorable to } \\
\text { computerization of tasks } \\
\text { 4.Top manager is much concerned }\end{array}$ \\
\hline
\end{tabular}


Enhancing Organizational Fit Factors to Achieve ERP Project Success/ Hung et al.

\begin{tabular}{|c|c|c|c|c|}
\hline Factor & $\begin{array}{c}\text { Operational Defini- } \\
\text { tion }\end{array}$ & $\begin{array}{l}\text { \# of } \\
\text { Item }\end{array}$ & Reference & Items \\
\hline & & & & $\begin{array}{l}\text { with the performance of ERP } \\
\text { operation } \\
\text { 5.Top managermakes and effort to } \\
\text { provide stable funding for the } \\
\text { ERP system development and } \\
\text { operation activities } \\
\text { 6.Top manager is much interested } \\
\text { in ERP usage rate } \\
\text { 7.Top manager frequently men- } \\
\text { tions the various problems and } \\
\text { matters related to ERP develop- } \\
\text { ment and operation }\end{array}$ \\
\hline $\begin{array}{l}\text { ERP Project } \\
\text { Success }\end{array}$ & $\begin{array}{l}\text { "The degree of de- } \\
\text { viation from project } \\
\text { goal in terms of ex- } \\
\text { pected cost, time, } \\
\text { system performance } \\
\text { and benefits." }\end{array}$ & 4 & $\begin{array}{l}\text { Hong and Kim } \\
(2002)\end{array}$ & $\begin{array}{l}\text { 1. The cost of ERP project was } \\
\text { significantly higher than the ex- } \\
\text { pected budgets. } \\
\text { 2. The ERP project took signifi- } \\
\text { cantly longer than expected. } \\
\text { 3. The system performance of ERP } \\
\text { is significantly below the ex- } \\
\text { pected level. } \\
\text { 4. The anticipated benefits of ERP } \\
\text { have notbeen materialized. }\end{array}$ \\
\hline
\end{tabular}

\section{About Authors}

Shin-Yuan Hung is an Information Systems Professor and the Dean of College of Management at National Chung Cheng University in Taiwan. He was a visiting scholar of the MIS Department at the University of Arizona during summer 2007-spring 2008. Prior to the leave, he had been the Secretary General of the same university. Dr. Hung received his bachelor degree in Statistics from the $\mathrm{Na}$ tional Chung Hsing University in Taiwan and his master and doctoral degrees in Information Systems from the National Sun Yat-sen University in Taiwan. His current research interests include decision support systems, knowledge management, electronic commerce, and data mining. He has published a number of papers in Decision Support Systems, Information \& Management, Electronic Commerce Research and Applications, Information Technology \& People, Communications of the AIS, Government Information Quarterly, Pacific Asian Journal of Associa- tion for Information Systems, Journal of Chinese Information Management, among others.

Wen-Ju $\mathrm{Yu}$ is a Ph.D. candidate of information management at National Cheng Chung University in Taiwan. Her current research interests include technology mediated learning, social commerce, and medical information system. She has published papers in Information \& Management and MIS Review.

Charlie C. Chen received his Ph.D. degree in Management Information Systems from Claremont Graduate University. Dr. Chen is an associate professor in the Department of Computer Information Systems at Appalachian State University. His current research interests are project management and supply chain management. $\mathrm{He}$ is a Project Management Professional (PMP) certified by the Project Management Institute. He has authored more than 90 referred articles and proceedings, presented at many professional 
Enhancing Organizational Fit Factors to Achieve ERP Project Success/ Hung et al.

conferences and venues. Dr. Chen has published in journals such as International Journal of Project Management, IEEE Transactions on Engineering Management, Behaviour and Information Technology, Communications of Association for Information Systems. Dr. Chen dedicates himself to be a transnational scholar and is a trip leader for study abroad programs in Japan, Taiwan, and Spain. He was a visiting faculty at Zhejiang
University in China and Gakushuin Women's College in Japan, and conducted forums on Supply Chain Management in Beijing University and Nanjing University.

Jung-Chang Hsu received his Master Degree from the Department of InformationManagement at National Chung Cheng University, Taiwan. He works as an assistant manager at the MIS department of UNIC Technology Corporation. 